\title{
An Economic Unravelling of the Precautionary Principle: The Queensland Wild Rivers Act 2005
}

\author{
STEPHEN ILES AND GARY JOHNS ${ }^{1}$
}

\section{Abstract}

The paper assesses the application of the precautionary principle in the Queensland Wild Rivers Act 2005. It finds that the Act is more restrictive than the ecologically sustainable development principles as conceived, and deployed, by the Queensland Government elsewhere. At the same time the Act is injurious to property rights, unnecessarily restricts future development options, and does not allow for assessments of non-environmental values or the cost of options forgone. As a result the Act has severe consequences for the Cape York economy and increases the risk of perverse consequences for the environment.

\section{Background}

Cape York Peninsula contains the largest areas of natural environment in eastern Australia within a land space slightly larger than Victoria. Unlike Victoria, which accommodates five million people at a high average standard of living, Cape York houses just 13000 people, the vast majority of whom live on welfare. Indigenous people make up more than 50 per cent of the population and own and/or control more than six million hectares, representing 45 per cent of Cape York's 13.7 million hectares. ${ }^{2}$ There is a major Welfare Reform program taking place on Cape York, designed to break widespread passive-welfare dependence and boost individual economic independence. In support of this major reform,

\footnotetext{
1 Stephen Iles, Cape York Institute; Gary Johns, Australian Catholic University, Gary.Johns@acu.edu.au. The original work for the paper was undertaken when both authors were consultants with ACIL Tasman Pty Ltd. The client was Balkanu Cape York Development Corporation. The authors would like to thank the two anonymous referees and the Editor for their comments.

2 Balkanu Cape York Development Corporation (unpublished correspondence).
} 
the Queensland and Australian governments have contributed \$100 million over four years. Nevertheless, the inhabitants are generally poorly equipped to face the serious environmental and economic threats to Cape York's biodiversity posed by invasive cane toads, wild pigs and other feral animals and grasses which impose great cost on Cape York.

An early attempt to satisfy the competing interests on Cape York had various interest groups sign the Cape York Heads of Agreement. The Cape York Land Council, The Wilderness Society, the Australian Conservation Foundation, the Cattlemen's Union and (some years later) the Queensland Government agreed:

All parties are committed to work together to develop a management regime for ecologically, economically, socially and culturally sustainable land use on Cape York Peninsula, and to develop harmonious relationships amongst all interest in the area. (Cape York Heads of Agreement 1996)

In 2005, the Heads of Agreement strategy was superseded, however, by the introduction of the Wild Rivers Act, legislation proposed by conservation groups in return for political support to the Queensland Government. More than a third of the total Cape York Indigenous estate is now designated for conservation purposes, mostly as national parks and nature refuges. ${ }^{3}$ The strategy behind the Wild Rivers Act appears to assume that the future of Cape York will be based on limited types of tourism and government transfers (environmental welfare), ${ }^{4}$ and that future residents will be unable to manage and develop land both to create wealth and preserve or indeed enhance the environment of Cape York. The Act has proved politically contentious and in 2010 the Federal Opposition vowed to introduce a Bill to the Commonwealth Parliament with the aim of overriding the Queensland legislation.

\section{The precautionary principle}

The Queensland Government seeks to protect the environment from future actions adverse to the environment. In doing so, it has drawn on the concept of Ecologically Sustainable Development (ESD) (Brundtland 1987), the widely accepted approach to jointly managing in the interests of the environment and development so as to protect the enjoyment of future generations in the environment. In order to achieve the desired balance of interests invoked by ESD, however, it is essential to apply some rule to manage the risk to the

3 Ibid.

4 A trial of 20 Wild River Rangers is under way across the Gulf and the Cape, with a total commitment of 100 rangers to eventually cover the entire Gulf and Cape declared Wild Rivers (Queensland Government 2009d). 
environment that development may bring. The widely applied rule is that of the precautionary approach or precautionary principle. The Queensland Government has applied this principle in its Wild Rivers Act.

At its simplest, the precautionary principle advises that a proponent should proceed with caution before undertaking an action where there is risk of possible harmful outcomes. Following Cussens (2009) and Soule (2000), it is clear that the apparently simple principle is not so simple after all. The principle, although widely invoked, does not necessarily assist in managing risk. For example, a widely accepted definition of the principle is known as the Wingspread Statement:

When an activity raises threats of harm to the environment or human health, precautionary measures should be taken, even if some causeand-effect relationships are not fully established. (quoted in Cussens 2009: 67)

The difficulty with the statement is that there is no definition of three crucial elements: threat of harm, uncertainty about risks and causal relationships, and the level of precaution in response to the threat. Cussens suggests that if threat of harm is taken to mean the actual risk of an activity, then the principle says too little; it is reduced to a cliché that tells us, 'when there is evidence of hazard, it is prudent to take care'. If, on the other hand, 'threat of harm' means the public perception of hazard, then the precautionary principle says too much; it can be invoked to slow or stop innovative, and possibly very beneficial, products or procedures, on the basis of lack of evidence (Cussens 2009: 67). To illustrate the bias of the principle, Cussens (2009: 69) formulates an alternative proposition: 'When a lack of activity raises a threat of harm to wealth creation, precautionary measures should be taken, even if some cause-and-effect relationships are not fully established.'

As Cussens argues, the statement has all the flaws of the Wingspread definition, but is nevertheless its 'logical equivalent'. Both are precautionary principles; where Wingspread has human and environmental health as its fundamental value, Cussens' version has wealth creation. Cussens' purpose is to illustrate that both versions are too vague to be practically applicable and that the usual version of the precautionary principle is value laden in what might be called a 'green' direction: 'A principle that is presented by its proponents in the guise of a value neutral guide to policy-making in the face of uncertainty is nothing of the kind.' (Cussens 2009: 69). 


\section{ESD and the application of the precautionary principle in Australia}

Perhaps reflecting the insight that the precautionary principle is value laden, one of the premier international environmental organisations, the International Union for the Conservation of Nature (IUCN), recently published guidelines (IUCN 2007: 6) for applying the precautionary principle to biodiversity conservation and natural-resource management. Crucially, the guidelines suggest that the principle be integrated with other relevant principles and rights. The IUCN cautions that other principles and rights, including intergenerational and intragenerational equity, the right to development, the right to a healthy environment, and human rights to food, water, health and shelter must be borne in mind when applying the precautionary principle:

In some circumstances these other rights may strengthen the case for precautionary action. In other circumstances, the Precautionary Principle may need to be weighed against these other rights and principles, taking into due account the critical nature of the Principle.

(IUCN 2007: 6) ${ }^{5}$

It is the contention of the paper that risk and uncertainty can never be avoided for either protection or development choices. For example, given the difficult circumstances of Aboriginal people in the Cape, Aboriginal development and unemployment are both uncertain under the protection and development options. There may be, for example, some irreversible effects of development opportunities lost forever under a stringent application of the precautionary principle. The ESD invoked by the IUCN and the Australian intergovernmental agreement seeks among other things, for example, to balance the needs of Aboriginal people and their desire to attain the living standards of other Australians and the needs of the environment. The difficulty is that the principle does not of itself provide a solution as to how these are to be achieved. The suspicion with Wild Rivers is that the principle is invoked in such a way as to allow the environment to trump the interests of Aboriginal economic aspirations. Rather than resort to such a crude use of the principle, it is possible to use management tools such as cost-benefit analysis to better understand, manage

5 Similarly, the national strategy for ecologically sustainable development adopted by the Council of Australian Governments in 1992 (Intergovernmental Agreement on the Environment) was careful to balance various principles and rights including, for example:

- to enhance individual and community well-being and welfare by following a path of economic development that safeguards the welfare of future generations

- to provide for equity within and between generations

- to protect biological diversity and maintain essential ecological processes and life-support systems. (Ecologically Sustainable Development Steering Committee 1992) 
and allocate risk and uncertainty. For example, the precautionary approach may encourage research that seeks to build knowledge and remove uncertainty, or apply sensitivity analysis that examines a range of possible outcomes and their response to changes in key variables. Most important, precaution used flexibly may accommodate the advance of knowledge and regulatory processes that require extensive testing to demonstrate reliability of outcome as well as prohibition of potentially damaging activity.

There is no single approach to the application of the principle in Australia. Indeed, Weirer and Loke (2007) count no fewer than 120 pieces of legislation and hundreds of 'non-binding policies' that invoke precaution in Australia, most of which reference the Intergovernmental Agreement on the Environment. The key question is to understand which version of the principle - between flexible and heavily restrictive — has been applied in Cape York under the Wild Rivers Act.

Various attempts have been made to formally classify the Australian approaches. The typology initially developed by Cooney (2004) and subsequently modified by Weirer and Loke (2007) is a good example.

Broad categories are as follows:

- Flexible applications seek to resolve uncertainty and not use uncertainty as a reason to avoid taking action. Cost-effectiveness may be a criterion for determining whether action should be taken.

- Moderately prescriptive responses narrow the field of reference for decisionmakers. Cost-benefit analysis and magnitude of impact are less influential.

- Heavily restrictive interpretations discard considerations of cost-benefit. An absolute threshold is frequently established to trigger action, regardless of scale or impact.

Within the broad categories, variants of the precautionary approach (Weirer and Loke 2007), differ over whether:

- a threshold for action is frequently established (often 'serious' or 'irreversible')

- associated costs and benefits are assessed

- action is required by decision-makers

- the burden of proof is reversed onto proponents to demonstrate that harm will not arise. 


\section{Assignment of costs}

The five tests summarised in Table 5.1 form the basis of the assessment framework to be applied to the Wild Rivers Act and have been formulated in conjunction with the three broad categories specified above.

\section{Threshold tests}

A trigger for invoking the principle can often be identified. Flexible applications often require an acknowledgement that consequences be sufficiently severe and have a degree of likelihood of occurrence. By contrast, heavily restrictive versions have no such requirement. The 'serious or irreversible' terminology is adopted in the Intergovernmental Agreement on the Environment and accordingly is categorised as flexible.

\section{Cost-benefit analysis}

Cost-benefit analysis is a second test to determine the strength and intensity of precaution in policy, regulation and legislation. The IUCN guidelines, the Intergovernmental Agreement on the Environment as well as the Cape York Heads of Agreement acknowledge the equal importance of conservation, intergenerational equity and economic and social development. An absence of cost-benefit analysis implies a preference for one of the latter three elements.

Irrespective of costs and benefits, an acceptance or assertion that an area has high preservation values can as a separate exercise lead to a search for the most cost-effective way of achieving those values. The IUCN guidelines and the Intergovernmental Agreement specifically cite the requirement for cost-effective responses.

\section{Burden of proof}

Reversal of the traditional burden of proof in relation to potential harm or damage in light of uncertain facts is a readily observed element of restrictive interpretations of precaution. Specifically, heavily restrictive versions require proponents to demonstrate that their proposed actions are entirely free from harm or damage. In contrast, flexible interpretations may not assign a burden of proof but, rather, simply remove uncertainty as a means of forestalling action to prevent harm. 
Neither the Guidelines nor the Agreement reverses the burden of proof, requiring developers to demonstrate freedom from harm. The Agreement does, however, call for 'fundamental consideration' of 'biological diversity and ecological integrity'.

\section{Costs}

Consideration of cost is a contested area. Weirer and Loke (2007) discuss the assignment of liability in the event of damage. Heavily restrictive interpretations clearly assign liability to development proponents, while flexible applications may not directly. The Agreement applies the 'polluter pays' principle and calls for developers to bear costs of 'containment, avoidance or abatement'. This paper more critically assesses the broader consequence of costs.

The specific incidence of cost is important. Some communities have greater capacity to bear costs. This fact explains differentiated expectations in climatechange debates. First-world nations, such as Australia and the United States are reasonably expected to incur greater costs now while rapidly industrialising nations, such as India and China, have lower expectations placed on them. Developing nations like Bangladesh have even lower capacities again. The Guidelines identify this aspect when it states the qualification, 'according to their capabilities'.

Attendant to discussion of current costs is consideration of intergenerational cost burdens. Precaution seeks to reduce the costs of damage and harm borne by future generations arising from the present consumption of resources. Flexible versions of precaution that acknowledge the requirement for a balanced treatment of competing aims, such as conservation and development, are keenly aware of intergenerational cost burdens arising from actions that limit either. Also, if sound, ecologically sustainable development is stopped for minor environmental reasons, or for environmental effects that can be mitigated, future generations suffer a loss of potential income (part of which could have been used for environmental protection). 
Table 1: The Comparison of Precautionary Principle applications of Weirer and Loke

\begin{tabular}{|c|c|c|c|}
\hline & Flexible & $\begin{array}{l}\text { Moderately- } \\
\text { prescriptive }\end{array}$ & Heavily restrictive \\
\hline $\begin{array}{l}\text { Is there a threshold } \\
\text { of threat for } \\
\text { triggering application } \\
\text { of the Principle? (a) }\end{array}$ & $\begin{array}{l}\text { Yes } \\
\text { For example, } \\
\text { 'significant', } \\
\text { 'irreversible', } \\
\text { 'serious' harm }\end{array}$ & Sometimes & No \\
\hline $\begin{array}{l}\text { Is an assessment } \\
\text { of the costs } \\
\text { and benefits of } \\
\text { alternative actions } \\
\text { required? }\end{array}$ & $\begin{array}{l}\text { Usually } \\
\text { Cost-effectiveness } \\
\text { may be applied }\end{array}$ & $\begin{array}{l}\text { Not usually } \\
\text { Cost-effectiveness } \\
\text { may be applied }\end{array}$ & $\begin{array}{l}\text { No } \\
\text { Cost-effectiveness } \\
\text { may be applied }\end{array}$ \\
\hline $\begin{array}{l}\text { Is precautionary } \\
\text { action required? }\end{array}$ & No & $\begin{array}{l}\text { Yes } \\
\text { Either required or } \\
\text { 'justified' }\end{array}$ & Yes \\
\hline $\begin{array}{l}\text { Is the burden of } \\
\text { proof assigned? (b) }\end{array}$ & $\begin{array}{l}\text { No } \\
\text { Depends on other } \\
\text { regulations }\end{array}$ & $\begin{array}{l}\text { No } \\
\text { Depends on other } \\
\text { regulations }\end{array}$ & $\begin{array}{l}\text { Yes } \\
\text { Developer/producer } \\
\text { bears the burden of } \\
\text { proof }\end{array}$ \\
\hline $\begin{array}{l}\text { Is liability for harm } \\
\text { assigned? (c) }\end{array}$ & No & No & $\begin{array}{l}\text { Usually } \\
\text { Developer/producer } \\
\text { bears liability }\end{array}$ \\
\hline
\end{tabular}

(a) Failure to satisfy the threshold test prevents the Principle being invoked but does not preclude precautionary action.

(b) The standard of proof is crucial in determining the practical effects of assigning liability.

(c) Liability is the legal obligation to provide compensation for damage resulting from an action for which the liable party is held responsible.

Source: (Weirer and Loke 2007: 7)

Costs also arise from distorted priorities. Heavily restrictive applications risk ignoring real and present dangers by placing too great an emphasis on distant and potential risks. Disproportionate responses that fail to deal with known and real risks now may impose significant costs on society.

Perverse consequences may also impose costs. Such consequences arise from heavily restrictive interpretations of precaution that mandate action, regardless of cost, in the event that the preventative or remedial actions taken are ineffective. Application of safety margins and improved information through research, evident in flexible approaches, may be more effective and minimise costs of action.

Well-established Australian expressions of the precautionary principle explicitly seek to balance consideration of economic and environmental consequences of decision-making. Specific acknowledgement is made of the fact that economic development pays for conservation. Section 3.3 of the Agreement states that: 
The parties consider that strong, growing and diversified economies (committed to the principles of ecologically sustainable development) can enhance the capacity for environmental protection. In order to achieve sustainable economic development, there is a need for a country's international competitiveness to be maintained and enhanced in an environmentally sound manner. (Australian Government 1992)

\section{Applying the framework to the Wild Rivers Act}

Initially, six Wild River Basins were declared in Queensland, with most situated in the Gulf of Carpentaria. Subsequently, four additional Wild River Basins Archer, Stewart, Lockhart, and Wenlock (Queensland Government 2009a, b, c, 2010) - have been declared in Cape York. A further eight Cape York river systems are scheduled to be declared.

\section{Wild Rivers Act is precautionary}

The Wild Rivers Act is clearly precautionary. Section three invokes precaution as a primary concept within the Act itself: '... having a precautionary approach to minimise adverse effects on known natural values and reduce the possibility of adversely affecting poorly understood ecological functions. (s3, 3, (b)) (emphasis added)

Additionally, precaution is raised in the Stewart River Consultation Report in response to questions from the public about the High Preservation Areas being declared to the maximum possible extent:

The department, in reviewing the proposed high preservation areas has considered the state of the natural values of the proposed wild rivers and adopted a precautionary approach in determining the width of the high preservation areas. (Queensland Government 2009d) (emphasis added)

\section{Disassociation from ESD}

The Wild Rivers Act specifically disassociates itself from ESD with the Explanatory Notes to the Act stating:

The Acts that regulate these resources and activities generally do not set development limits at the catchment scale. Those Acts that do set limits, generally do so under the principles of ecological sustainable development (ESD), which permits a loss in natural values to achieve economic and social benefits. The level of preservation sought for wild 
rivers, which have all or almost all of their natural values intact, is higher than for ESD but below that generally provided in a national park. (Wild Rivers Bill 2005: Explanatory Notes) (emphasis added)

The Notes go on to establish the absolute importance of preservation:

Hence it is necessary to clearly specify limits on resource allocations and activities for the purpose of preserving the natural values of wild river systems. (Wild Rivers Bill 2005: Explanatory Notes) (emphasis added)

The term 'preserve' has a different meaning to the term 'conserve'. Preservation does not permit any changes, while conservation allows the ongoing management and does contemplate change. This effectively unbundles the three equally important core principles of the National Strategy for Ecologically Sustainable Development of economic development, intergenerational equity and biological diversity. This is in violation of the Queensland Government's COAG commitments. The Act is precautionary in its approach and it specifically disassociates itself from the well-founded principles of ESD in a number of ways.

\section{Low threshold test}

The Explanatory Notes recognise that pressure to develop Cape York is 'limited' and 'little' development has historically taken place:

the level of future development is not expected to be high. Wild rivers tend to be in regions of the State where little development has occurred and generally have limited development pressure. (Wild Rivers Bill 2005: Explanatory Notes) (emphasis added)

This establishes a very low threshold for action. Not only are there few expected threats of damage, but that these threats are currently being constrained by existing legislation and regulation.

\section{Precludes cost benefit analysis}

The Explanatory Notes to the Act explicitly preclude consideration of costbenefit analysis by stating:

While wild rivers may contain or support other values, such as economic, social, scientific, educational and Indigenous, the Bill is intended to preserve the natural values listed above. (Wild Rivers Bill 2005: Explanatory Notes) (emphasis added)

Here, the Act establishes the primacy of preservation, rendering the other values secondary and outside the scope of the legislation. In expanding on the 
purpose of the Act, the Explanatory Notes introduce the concept of "necessary development' without defining it. In the absence of cost-benefit analysis, necessary development is clearly understood on purely conservation grounds:

The aim of the Bill is to ensure that a declared wild river's environment is maintained in its largely natural state, and impacts from necessary development minimised. (Wild Rivers Bill 2005: Explanatory Notes) (emphasis added)

Like any policy, the Wild Rivers Act imposes, either implicitly or explicitly, costs and benefits (Rolfe 1995). There has been no assessment of these to check that adverse costs are not too high. The justification of the Wild Rivers Act would normally involve an assumption that the benefits of conservation outweigh the costs. No assessment of the costs and benefits of individual declarations has been undertaken to identify whether it is worthwhile for a river to be declared. This underscores the earlier observation that the Act unbundles the ESD package of equally important core objectives detailed in the National Strategy and the Cape York Heads of Agreement. The Wild Rivers Act removes any consideration of elements outside natural preservation, including cost-benefit analysis. It is heavily restrictive legislation.

\section{Reverses burden of proof}

A burden of proof, to be carried by the applicant, is clearly established by the Act at two stages.

- At the property development plan stage

- At the ministerial decision-making stage.

The Wild Rivers Code is very explicit in its application of precaution:

When determining whether an application meets the required outcome, the assessment manager must take a precautionary approach that is, not use the lack of full scientific certainty as a reason for not imposing requirements or conditions to minimise potential adverse effects on the natural values. The onus lies with the applicant to demonstrate that a proposed development or activity meets the required outcomes of the code. (Queensland Government 2007) (emphasis added)

\section{Is highly restrictive}

A proponent of a prohibited development in a Highly Protected Area (HPA) can seek to have the prohibited development assessed by lodging a Property 
Development Plan. Approval of the Plan does not result in approval to proceed. Rather, the approved Plan forms the basis for a change to the Wild River Declaration.

Consideration of a property development plan under the Wild Rivers Code is, therefore, clearly forbidden. Further, a proposal under a Plan must be assessed with reference to:

the nature and extent of any other thing proposed to be done in addition to the activities, or the taking, that would result in a beneficial impact on the natural values of the relevant wild river (s31D, 1, (j)) (emphasis added)

Not only must the proponent demonstrate that no harm will arise from the proposed development, the proponent must demonstrate a beneficial impact on conservation values! This narrowly defined beneficial environmental impact is well outside the scope of ESD. Well-defined and accepted Australian interpretations of ESD place no requirement of proof on proponents. The Act is clearly highly restrictive, a finding reinforced with reference to Ministerial decision-making. Any proposed amendment is also subject to the consideration of public submissions and, ultimately, ministerial decision. Once a property development plan is considered by the relevant minister, the minister is required to ensure that the proposed amendment: 'will not have an overall adverse impact on the natural values of the wild river. (s31E(b)) (emphasis added)

And that further: 'the environmental benefits of the plan justify the approval of the plan. (s31E(c)) (emphasis added)

The proposed amendment must demonstrate that the property development plan has positive environmental benefits and not simply an absence of harm.

The process for ministerial decision is lengthy and expensive. For example, a proposed plan has to be submitted with a fee and assessed by an independent panel of scientists expert in hydrology, geomorphology, water quality, riparian function and wildlife movement. If the minister approves the plan, with or without conditions, the minister can then seek to amend the declaration through the current formal process, including public consultation and submission. Based on submissions, the minister will then make a decision whether to amend the declaration. If the declaration is amended the landholder will then have to submit applications for each development and go through the normal assessment process under the Integrated Planning Act or other relevant act. This means that the developments will have to meet the wild rivers requirements. Also, to prevent the landholder later choosing to capitalise on the amended declaration and applying to do something else all developments on the property for the 
next 10 years have to be in accordance with the plan (Weekly Hansard 2007). With respect to decision-making, the Wild Rivers Act is a highly restrictive interpretation of the precautionary approach.

\section{Is costly}

The Act's heavily prescriptive approach precludes assignment of direct costs arising from damage to developers - the 'polluter pays' concept. Liability is irrelevant, as many developments in HPA zones are simply prohibited. Allowable developments in HPA and Protected Area (PA) zones are assigned liability for damage under existing legislation (for example, the Environmental Protection Act (1994)). A broader range of cost considerations must also be taken into account when testing the severity of precaution in the Act (Cooney 2004).

Wild Rivers specifically excludes consideration of costs beyond a narrow interest in loss of natural preservation values. While the Act specifically acknowledges the presence of other competing interests, it clearly disregards them. In doing so, costs associated with lost economic development opportunities and social exclusion are precluded from consideration in the operation of the Act. Decisions are made purely on the basis of environmental benefit. This places significant potential opportunity costs on society.

\section{Neglects intergenerational equity}

In as much as Wild Rivers implicitly acknowledges intergenerational equity by seeking to preserve amenity for future generations, it achieves this only in part. While it seeks to conserve Cape York's river catchments for future generations, it ignores the economic and social well-being of these same future generations. Heavily restrictive conservation policy that is disassociated from ESD eliminates current development opportunities and also eliminates all future opportunities. ESD gives full voice to future generations by limiting current and future development that does not maximise welfare. The singular focus on future enjoyment of the environment, at the expense of future economic and social welfare, makes the Act heavily restrictive.

\section{Treats landowners inconsistently under the Act}

A further matter, not readily fitting within the Weirer and Loke framework but worthy of consideration nevertheless, is that the Act treats the current and future options of landowners inconsistently. For example, the Act purports to make provision for current and future mining, fishing and grazing. In the Second Reading Speech to parliament on 24 May 2005 the minister gave clear 
guidance that the Act provided 'enhanced opportunities' for grazing and fishing. Speaking to subsequent amendments to the Act during the Second Reading on 31 October 2006, the minister permitted minerals exploration and below-ground mining.

What the Act does is prohibit and regulate a wide range of lower-level activities such as tourism and market gardens, for example. The Act seems disproportionate in its response to the actual threats posed to Cape York as opposed to distant and uncertain threats. This necessarily imposes costs. The established Australian legislative and regulatory practice of ESD specifically seeks to minimise costs by allowing wide consideration of costs and benefits attributable to conservation, development and intergenerational equity and selecting options that maximise total benefits, net of costs.

Section 17 of the Act specifically recognises and protects property owners who have elected to develop their land already: 'This clause preserves existing rights of entities to carry out activities and take natural resources.' (Wild Rivers Bill 2005: Explanatory Notes)

Activity that was being carried out prior to declaration and activity that was authorised prior to any declaration under the Act is allowed to continue despite the subsequent operation of the Act. The Queensland Government denies claims that any rights are injured (Queensland Government 2009d) but, compensation issues aside, the very recognition of pre-existing rights implies that future rights may be degraded. This point is underscored by the fact that Property Development Plans across a range of activities in HPAs will not be accepted and are deemed to be improperly made.

Applying the options framework to these circumstances suggests that options already exercised are recognised and protected but future options as yet unexercised are not recognised and not protected.

\section{The rights to future options are injured}

In the instance of significant injury to property owners' range of future options, governments frequently compulsorily acquire the property. The Australian Government is constitutionally compelled to compensate property owners 'on just terms' when compulsorily acquiring property. While State governments are not compelled to apply just-terms compensation, they frequently do so (Nicholls 2008). 
When future options are only modestly injured, compensation is a cost effective alternative to compulsory acquisition. This recognises that future options are potentially impaired in the instance of government decision making. (Ibid)

The Wild Rivers Act offers neither compensation nor compulsory acquisition, an aspect of the legislation that the Scrutiny of Legislation Committee commented on as follows:

It appears to the committee that the only circumstance in which existing rights might potentially be adversely affected by a wild river declaration would be if a declaration affected freehold land. In such cases the general common law right of landowners of freehold land to use that land (subject to not causing 'nuisances' to adjoining landowners) in whatever manner they see fit would probably be inhibited. (Scrutiny of Legislation Committee 2005)

The Act employs a device under the Integrated Planning Act that mandates that certain development applications cannot be considered by the department or the minister.

Injury to the rights of property owners is particularly relevant under Wild Rivers. Declaration of Wild Rivers and the high-preservation zone is made regardless of the property type. Future options available to affected owners are potentially severely curtailed, yet the State makes no offer of restitution for these lost options. This is particularly significant as options are being restricted while tenure resolution is under way through State Land Dealings.

Property owners are potentially faced with injurious impacts to their possible future options. The minister underscored this point in the Act's initial Second Reading speech stating: 'Very few activities will be permitted in the waterway itself or in the 'high preservation' area, including a buffer up to one kilometre wide on each side of the river.' (Weekly Hansard 2005)

The Act 'does not limit the matters the Minister may consider' (Wild Rivers Act 2005). It does, however, direct the minister to consider:

- the results of community consultation on the declaration proposal

- all properly made submissions about the declaration proposal

- any water-resource plan or resource-operations plan that applies to all or part of the proposed wild river area.

The Wild Rivers Act fails to recognise that Property owners have 'standing' and are not simply unrelated third parties to the legislation and its direct impacts. Third-party voices are given equal treatment and the Act has no basis 
to establish or differentiate the voices. In a best-practice guide published by the World Conservation Union, Cooney (2004) observes that issues of inappropriate incidence of cost burden are 'intimately tied to the question of who is involved and represented in the decision-making process'. Simply appearing as one of many individuals and organisations that participated in a consultation forum does not equate to involvement and representation in decision-making. Cooney then cautions against abuse of the precautionary principle that renders it merely as a 'rhetorical tool of convenience'.

\section{Conclusion}

Many of the arguments made by the Queensland Government for the preservation of Cape York could apply to any river in Queensland. A key reason for the focus on Cape York is that the costs of preservation are seen to be low. If this were not so, the legislation would apply everywhere in Queensland. The real problem with the Act is that some general assessment of costs and benefits is being used to select the rivers for declaration, but this is not explicit, and there is no use of costs and benefits to temper the application of the policy on a case-bycase basis. The Wild Rivers Act applies a highly restrictive interpretation of the precautionary principle that unnecessarily limits property owners' future options. Future ESD options on Cape York are currently subject to significant and excessive restrictions. These include:

- legislation such as the Vegetation Management Act 1999

- the current nature of land tenure which is not conducive to the economic use of land.

There is an ever-expanding set of possible future limitations to ESD options in Cape York. The Wild Rivers Act sets a dangerous precedent by radically departing from the well-established and widely understood Australian commitment to the principles of ESD and their equally important foundational concepts. Other possible future limitations to ESD options include:

- World Heritage listing (currently proposed by the State and Commonwealth Governments)

- Australian Heritage listing (proposed by Humane Society International)

- Climate change.

ESD actively seeks to maximise the range of potential future options available to land owners. It explicitly maximises both economic and environmental options. looks at Wild Rivers and ESD in relation to the maximisation of environmental and economic value. The upper-right quadrant defines high economic value 
and high environmental value. The lower-left quadrant identifies low economic and low environmental value. High economic and low environmental value is described by the upper-left quadrant, while low economic and high environmental value is defined in the lower-right corner.

National Parks maximise environmental options but explicitly limit economic options. The Act maximises neither. From an options perspective, National Parks may restrict future potential land-use options to a similar extent as mining. Mining has some irreversible destructive impacts on the environment. National Parks and the conceptual extension of natural-value preservation on private land through Wild Rivers are in practice irreversible. Some governments are now reliant on green electoral preferences. Ascent to power would be blocked to political parties advocating the abolition of a National Park. The onerous legislative process specified in the Act for Wild River Declaration amendments is also likely to ensure practical irreversibility.

The Wild Rivers Act is too narrowly focused. It assumes that the only potential risks are environmental. Welfare Reform has demonstrated the risks associated with a lack of development and social engagement. These risks have also been shown to be intergenerational.

Figure 1: Ecologically sustainable development assessment of Wild Rivers

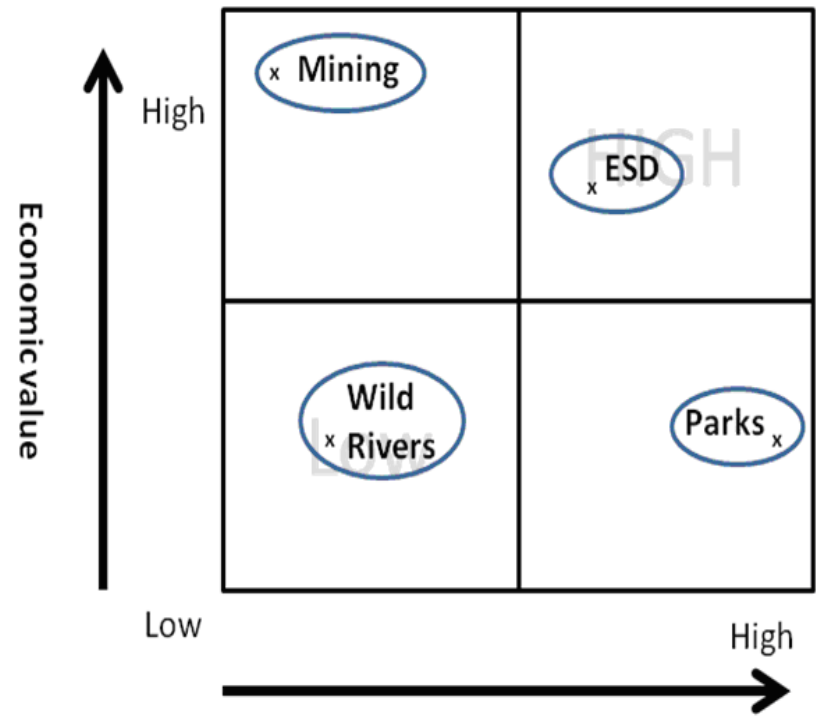

Environmental value

Note: ESD = Ecologically sustainable development; Parks = National Parks Source: Authors. 


\section{References}

Arrow, K. and Fisher, A. 1974, 'Environmental Preservation, Uncertainty, and Irreversibility', Quarterly Journal of Economics 88(2): 312-19.

Australian Government 1992, Intergovernmental Agreement on the Environment, Department of the Environment, Water, Heritage and the Arts: http://www. environment.gov.au/esd/national/igae/index.html

Brundtland, G. H. 1987, Our Common Future, World Commission on Environment and Development.

Cape York Heads of Agreement 1996, The Wilderness Society: http://www. wilderness.org.au/articles/agreement/?searchterm = cape york heads of agreement

Cape York Institute 2009, The economic potential of emerging markets for carbon and biodiversity for Cape York Indigenous people, Cairns: Cape York Institute for Policy and Leadership.

Cooney, R. 2004, 'The Precautionary Principle in Biodiversity Conservation and Natural Resource Management: An issues paper for policy-makers, researchers and practitioners', Gland, Switzerland and Cambridge, UK: IUCN.

Cussen, K. 2009, 'Handle with Care: Assessing the Risks of the Precautionary Principle', Australasian Journal of Environmental Management 16(2): 66-9.

Ecologically Sustainable Development Steering Committee 1992, National Strategy for Ecologically Sustainable Development, Department of the Environment, Water, Heritage and the Arts: http://www.environment.gov. $\mathrm{au} / \mathrm{esd} /$ national/nsesd/strategy/index.html

Farrow, S. 2004, 'Using Risk Assessment, Benefit-Cost Analysis, and Real Options to Implement a Precautionary Principle', Risk Analysis 24(3): 727-35.

Gollier, C. and Treich, N. 2003, 'Decision-Making Under Scientific Uncertainty: The Economics of the Precautionary Principle', The Journal of Risk and Uncertainty 27(1): 77-103.

International Union for the Conservation of Nature 2007,'Guidelines For Applying The Precautionary Principle To Biodiversity Conservation And Natural Resource Management', 67th meeting of the IUCN Council 14-16 May 2007. 
Nicholls, D. 2008, Compensation for Injurious Affection Caused by Planning Instruments - Is it Withering on the Vine? Brisbane: Hopgood Ganim Lawyers.

Queensland Government 2009a, Archer Basin Wild River Declaration, Brisbane: Department of Environment and Resource Management.

Queensland Government 2009b, Lockhart Basin Wild River Declaration, Brisbane: Department of Environment and Resource Management.

Queensland Government 2009c, Stewart Basin Wild River Declaration, Brisbane: Department of Environment and Resource Management.

Queensland Government 2009d, Stewart Basin Wild River Declaration Consultation Report, Brisbane: Department of Environment and Resource Management.

Queensland Government 2010, Wenlock Basin Wild River Declaration, Brisbane: Department of Natural Resources and Water.

Queensland Government 2007, Wild Rivers Code, Brisbane: Department of Natural Resources and Water.

Rodrigues-Neto, J. A. 2008, 'Climate Change Policy: A Theorist's Plea to Take Heed of Game Theory and Ambiguity Aversion', Agenda 15(2): 85-90.

Rolfe, J. 1995, 'Ulysses Revisited: A Closer look at the Safe minimum Standard Rule', Australian Journal of Agricultural Economics 39(1): 55-70.

Scrutiny of Legislation Committee 2005, Alert Digest (7 June) Brisbane: Queensland Parliament.

Soule, E. 2000, 'Assessing the Precautionary Principle', Public Affairs Quarterly 14(4): 309-28.

United Nations Conference on Environment and Development 1992, Rio Declaration on Environment and Development, UN Documents: Gathering a Body of Global Agreements: http://www.un-documents.net/rio-dec.htm

Weekly Hansard 2005, May 24 Queensland Parliament: http://www.parliament. qld.gov.au/hansard/

Weekly Hansard 2006, October 31 Queensland Parliament: http://www. parliament.qld.gov.au/hansard/

Weekly Hansard 2007, February 22 Queensland Parliament: http://www. parliament.qld.gov.au/hansard/ 
Agenda, Volume 17, Number 2, 2010

Weirer, A. and Loke, P. 2007, 'Precaution and the Precautionary Principle', Productivity Commission Staff Working Paper.

Wild Rivers Act 2005.

Wild Rivers Bill 2005: Explanatory Notes.

Wild Rivers Regulation 2007. 